\title{
Between Patronage and Professional Writing. The Situation of Eighteenth Century Women of Letters in Venice: The Example of Luisa Bergalli Gozzi
}

\author{
Rotraud von Kulessa
}

\begin{abstract}
In the eighteenth century, Venice was the centre of Italian publishing and culture. Drama writers, such as Carlo Goldoni, were among the first professional writers in eighteenth-century Italy. A large part of the literary field there was dominated by translation and journalism, both of which attracted some prolific women writers, such as Luisa Bergalli Gozzi and Elisabetta Caminer Turra. This chapter will analyse the material implications of the literary production by Luisa Bergalli between patronage and professional writing.
\end{abstract}

Pietro Chiari underlines the material aspects of women writing in eighteenthcentury Italy, in the fictional editorial prefaces of one of his numerous novels ${ }^{1}$ written in the form of fictional memoirs by fictional female authors. ${ }^{2}$ Chiari was a polygraph and wrote for theatre, a field in which he was in competition with Carlo Goldoni and Carlo Gozzi. He also produced about 5 o novels, ${ }^{3}$ which were pre-eminently addressed to a female public in order to promote the principles of Enlightenment. Chiari's positive statements about Italian eighteenthcentury women's writing cannot be taken seriously, but need to be resituated

1 Pietro Chiari, La Francese in Italia o sia Memorie critiche di Madama N.N. scritte da lei medesi$m a$, Venice 1806, 15: "I libraj oggidì non vendono che romanzi, ed io non devo pertanto scrivere che soli romanzi, se scriver voglio de' libri, che sieno venduti, e convertino in oro l'inchiostro dell'angusta miniera a me lasciata in retaggio dalle umane vicende. Scrivete adunque, madama, voi stessa scrivete le memorie della vostra vita, se volete arrichire le stampe d'un libro che vi faccia qualche fortuna."

2 For the romance production of Chiari see Luca Clerici, Il romanzo italiano del Settecento, Venice 1997 .

3 Luca Clerici, Il romanzo italiano del Settecento, Venice 1997, 19ff. 
in the context of the debate about the state of the Italian novel and his quarrel with Carlo Gozzi. ${ }^{4}$ Carlo Gozzi was an enemy of the ideas of Enlightenment and all progressive evolution in the literary field, such as the participation of women. Contrary to this, Chiari often cites the example of French women writers; they were not as numerous in Italy, even thought Italian female readership was significant.

In the context of eighteenth-century Venice, two prolific women of letters were notable: Luisa Bergalli Gozzi and the older Elisabetta Caminer Turra. ${ }^{5}$ Both were also outstanding in critical writing and translation. This chapter will focus on the example of Bergalli, as her literary career follows a transition from patronage to professional writing, in which she tries to obtain a financial benefit from her professional literary work. Furthermore, her case is interesting because of the diversity of her literary activities and her awareness of female literary genealogies.

Luisa Bergalli was born on 16 April 1703 in Venice. Despite her lower-class origins, ${ }^{6}$ her father was an artisan and she received an education complemented by painting lessons from the famous Venetian painter, Rosalba Carriera, along with a foundling relationship with the melodrama writer Apostolo Zeno. ${ }^{7} \mathrm{Her}$ friendship with Rosalba Carriera began a long and productive exchange, ${ }^{8}$ not only an artistic one, but also on the level of consecration in the literary field. Apostolo Zeno became her protector. By initiating her in the dramatic genre of melodrama, ${ }^{9}$ Zeno was responsible for her acceptance as writer of the melodrama Algide for the theatre San Moisé in 1725. Bergalli also wrote a tragedy in 1728 (Teba) and a comedy entitled Le Avventure del Poeta (The Adventures of the Poet) in 1730. Apostolo Zeno might have been responsible for Bergalli's admission to the Academia of Arcadia where she used her Arcadian name,

4 See Rotraud von Kulessa, "Il gioco con l'illuminismo nel contesto veneziano: I romanzi di Pietro Chiari come esempio di polemica e gioco in letteratura", in Conflitti culturali a Venezia dalla prima età moderna ad oggi eds Rotraud von Kulessa et al, Florence 2014, 59-74.

5 Rotraud von Kulessa, "Elisabetta Caminer Turra. Traductrice, médiatrice et 'organisatrice culturelle" , in Femmes écrivains à la croisée des langues 1700-2000 eds Agnese Fidecaro, Henriette Partzsch, Suzan Van Dijk, Genève 2009, 55-66.

6 About the biography of Luisa Bergalli, see Carlotta Egle Tassistro, Luisa Bergalli Gozzi. La vita e l'opera sua nel suo tempo, Rome s.d.

7 Unfortunately, we lack reliable sources about her getting in contact with Zeno.

8 See Catherine M. Sama, "On canvas and on the page. Women shaping Eighteenth Century Italy", in Italy's Eighteenth Century. Gender and Culture in the Age of the Grand Tour eds Paula Findlen, Wendy Wassyung Roworth and Catherine M. Sama, Stanford 2009, 125-50.

9 For the full list of her works, see Adriana Chemello, "Luisa Bergalli letterata di chiara fama", in Luisa Bergalli. Poetessa drammaturga traddutrice critica letteraria. Atti del convegno ed. Adriana Chemello, Mirano/Venice, 2007, 20-22. 
Irminda Partenide. With the publication of her Componimenti Poetici delle Più Illustri Rimatrici di Ogni Secolo (Compositions of the Most Known Women Poets of Every Century) in 1726, Bergalli proved to be especially aware of this particular female literary tradition. ${ }^{10}$ This project was followed by the publication of an edition of the Rime by the Renaissance poet Gaspara Stampa in 1738, which followed the publication of the Rime by Antonio Sforza, her Latin teacher, in 1736. In July 1738, Luisa Bergalli married Gasparo Gozzi, who was ten years her junior. Gozzi came from an old aristocratic Venetian family, which she likely knew through Apostolo Zeno. Her future father-in-law ordered the comedy Le Avventure del Poeta in 1730 and Bergalli contributed to the consecration of the two literary hopes of the family: Carlo and Gasparo Gozzi. ${ }^{11}$ Bergalli was 35 years old when she married and bore five children in the first five years of her marriage. However, after the death of her father-in-law, Iacopo Antonio Gozzi, misfortune befell the Gozzi family: the wealth of the family was squandered and Bergalli's brother-in-law, Carlo Gozzi, the famous antagonist of Carlo Goldoni in his comedic quarrel, accused her of having lost the family's money through her literary activities. ${ }^{12}$ This judgment would, in fact, determine the reception of Bergalli throughout the entire nineteenth century and was revisited only at the beginning of the twentieth century. ${ }^{13}$

The Gozzi couple had to earn money in order to support their large family, and they attempted this through their literary activity. This marriage therefore also marked the shift from patronage to professional writing in the life of Bergalli. Up to this point, the financial reward from their literary activities was dependent on the opinions of patrons. The Gozzi couple's first project was in the direction of the Theater Sant Angelo for one year, between 1747-1748. This failed and was an economic disaster. They also collaborated in a substantial number of translations from French. Bergalli translated Terence from Latin, ${ }^{14}$ Molière ${ }^{15}$ and Racine from

10 See Rotraud von Kulessa, "L'autrice dans l'historiographie littéraire italienne (du 18e siècle jusqu’à l'époque 1900) et l'identité culturelle”, in Pour une histoire genrée des littératures romanes eds Annette Keilhauer/Lieselotte Steinbrügge, Tübingen 2013, 25-36.

11 See Fabio Soldini, "Luisa Bergalli e i Gozzi”, in Luisa Bergalli ed. Adriana Chemello, 36.

12 Carlo Gozzi, Memorie inutili, Bari 1910, vol. 1, 144-45: "Negai l'inaspettata e mostruosa pretesa di crediti della cognata, per quanto sarebbe da' giudici considerato. E perché ella sosteneva d'essere creditrice da noi per essere debitrice a parecchi creditori che avevano a lei affidate merci per i bisogni della famiglia, oblazioni che verificati e liquidati cotesti crediti, sarebbero i creditori risarciti". see also Ibid., 117, 130-32, 134, 143, 148-49, 158.

13 Luisa Bergalli Gozzi, Le avventure del poeta ed. Luisa Ricaldone, Manziana 1997, 9.

14 Le commedie di Terenzio tradotte in verso sciolto (col testo latino al fianco), Venice 1733.

15 Il Misantropo. Commedia tratta da Molière, e messa in versi italiani da Irminda Partenide, Venice 1745 . 
French. ${ }^{16}$ When the French poet Anne-Marie du Boccage came to Venice in 1757, she translated her tragedy Les Amazones, which had been published in a prestigious bilingual edition in $1756 .{ }^{17}$ From 176 o onward, the name of Bergalli became less visible, as she stayed in the shadow of her husband. In fact, many of the attributions of either Gasparo or Bergalli are uncertain. We know that they undertook a translation of Claude Fleury's Histoire Ecclésiastique, a masterpiece in 27 volumes and about 12,000 pages, but only the name of Gasparo Gozzi was credited on the translation. The story of Bergalli is therefore the pursuit of literary fame in order to sustain her husband and save her family from financial ruin, as revealed by her son Francesco. ${ }^{18}$ Her son underlines her efforts to support the material conditions of her large family and investigates her literary activities (such as translation) not particularly honourable, but promising some financial reward.

In order to demonstrate the shift from patronage to professional writing in Bergalli's literary career, I will first look closer at the Venetian literary field of the eighteenth century. Then I will analyse the period of Bergalli as a playwright and especially the case of the comedy Le Avventure del Poeta. Finally, I will focus on the literary activity of the Gozzi couple, which marks the shift to professional writing. ${ }^{19}$

\section{Literary Life in Venice in the Eighteenth Century}

In spite of the political and economic decline of the Serenissima in the eighteenth century, Venice was the centre of European tourism and culture ${ }^{20}$ with a flourishing literary market. ${ }^{21}$ In particular, in the second half of the century, it had the most theatres in all of Europe. ${ }^{22}$ Since the Renaissance, and with

16 Opere di M. Racine, 2 vol., Venice $1736 / 1737$.

17 Le Ammazoni. Tragedia della Signora Du Boccage. Tradotta nell'Italiana favella da Luisa Bergalli Gozzi, Veneziana. E stampato col testo francese, Venice 1756.

18 See Fabio Soldini, "Contributo agli studi su Gasparo Gozzi. Gli inediti 'Frammenti di Memorie' di Francesco Gozzi”, Giornale storico della letteratura italiana, CXLV/450-451 (1968), 369-402.

19 Unfortunately, little information about the economic details of her literary work exists. There are no letters left from her negotiations with editors, etc. Our sources are limited to the letters of Apostolo Zeno, of her husband, the Memorie inutili di carlo Gozzi and the fragments of the memoirs of her son Francesco, presented by Fabio Soldini (op.cit.).

$20 \quad$ Alvise Zorzi, Histoire de Venise, Paris 2000, 440.

21 Mario Infelise, L'editoria veneziana nel ' 700 , Milan 1989.

22 Nicola Mangini, I teatri di Venezia, Milan 1974, 91-93; Robert Fajen, Die Verwandlung der Stadt. Venedig ind die Literatur im 18. Jahrhundert, München 2013, 46-48. 
the appearance of the famous publisher Aldo Manuzio, Venice was one of the centres of the European publishing industry. ${ }^{23}$ The economic impact of publishing remained significant for the Republic in the eighteenth century and relative autonomy from the Catholic Church made the practice of censorship comparatively flexible. ${ }^{24}$ Venice, therefore, became the Italian market for the ideas of the Enlightenment, especially in drawing intellectual thought from France. In this context, professional writers were given a chance to invest in popular literary genres, such as the novel. The female public especially appreciated this genre. ${ }^{25}$ It was also in this period that significant translations and adaptations of French literature appeared. ${ }^{26}$

Theatre also featured as the object of translations from French to Italian. At the beginning of the eighteenth century, Italian drama was still dominated by the Commedia dell'arte and the melodrama of Apostolo Zeno. The absence of alternatives gave birth to the famous Goldonian reform of the Italian comedy. Inspired by French comedy of Molière and the new dramatic forms of the comédie larmoyante or the drame bourgeois, Goldoni tried to replace the character improvisation of the Commedia dell'arte by using real characters and the representation of Venetian society of his time. Translations of French drama of the seventeenth and second half of the eighteenth century were hugely popular, especially, of the new French drama genres: the comédie larmoyante or the drame bourgeois. Like Elisabetta Caminer Turra some years later, Bergalli and her husband Gasparo Gozzi were engaged in this field not only to renew the tradition of Italian drama on behalf of the enterprise of translation, ${ }^{27}$ but also to earn money. According to Mario Infelise, in eighteenth-century Venice,

23 Alessandro Marzo Magno, L'alba dei libri. Quando Venezia ha fatto leggere il mondo, Milan 2012.

24 Infelise, L'editoria, 62-65.

25 Maria Rosa Zambon, Bibliographie du roman français en Italie au XVIIIe siècle. Traductions, Paris 1962, VII: “C'est un phénomène complexe sous plus d'un aspect que la vaste influence exercée par la France en Italie au XVIIIe siècle. Dans tous les domaines, les modes françaises ont précédé la véritable influence de la culture. Les femmes qui ont tant de part dans la formation du goût, étaient alors, comme aujourd'hui éprises des modes de Paris que les différentes gazettes, plus ou moins littéraires, célébraient sans cesse."

26 Luigi Ferrari, Le traduzioni italiane del teatro tragico francese nei secoli XVII e XVIII, Paris 1925, XIV: "Nella seconda metà del '70o i traduttori non si contano più. Si traduce da tutte le categorie di scrittori, da uomini di ogni ceto sociale, per pur diletto estetico, per esercitazione stilistica, per ragioni commerciali, per fini pratici di rappresentazione sulle scene, per appagare il generale desiderio di conoscere le opere francesi e di tenersi al corrente di quel repertorio."

27 Rotraud von Kulessa, "Elisabetta Caminer Turra (1751-1796) e L'Europa letteraria: alcune riflessioni sulla traduzione”, Circula: revue d'idéologies linguistiques 1/2 (2015). 
there was no legislation on literary property and authorial rights. However, if a text was requested by an editor and published, but not at the expense of the author - which was often the case - an author could earn about $23-24 \%$ of the profits from the book. ${ }^{28}$ For a book with 3,00o copies, earnings could equate to around 440 Lira and, for a translator of a volume of about 1,00o copies, the profit could be 272 Lira. ${ }^{29}$ According to Infelise, authors such as Gozzi, complained about the difficulties of working with editors. ${ }^{30}$ The most striking example of professional (dramatic) writing is the well-known case of Carlo Goldoni, who was contracted with Girolamo Medebach, impresario of the theatre of Sant Angelo, to write 8 comedies and 2 alternate plays annually for a period of 4 years for 450 Ducati per year. ${ }^{31}$ Goldoni defended the profession of the playwright in the introduction to his metapoetical play Il Teatro Comico $\left(175^{\circ}\right) .{ }^{32}$

\section{Luisa Bergalli as a Drama Author or Self-Reflection about the State of Poet}

The first play that Bergalli published was the melodrama Agide 33 in 1725. Apostolo Zeno - who was her intellectual mentor and had recommended her to some influential personalities of Venetian culture - used a trick to get the play of the young author accepted by the important Venetian theatre, S. Moise. When the theatre called him to write a melodrama, he said that he did not have enough time and sent Bergalli's play instead. He then published a very favourable critique in the Giornale dei Lettori d'Italia. The same Zeno influenced Bergalli's play, along with Racine, an author she translated in 1736/37. In 1723, Apostolo Zeno wrote to the young authoress to praise her melodrama, give advice and correct her manuscript. ${ }^{34}$ One year later, Zeno recommended her

28 Mario Infelise, L'editoria, 189-9o.

29 Mario Infelise, L'editoria, 190-91.

$30 \quad$ Mario Infelise, L'editoria, 191-92.

31 Mario Infelise, L'editoria, 197: "La coraggiosa initiative del Goldoni è ormai indicative dell'esistenza di un nuova tipo d'intellettuale, decisamente sganciato da voncoli di subordinazione nei riguardi di qualche potere e de qualche atristocratico mecenate." It is not possibile to define the exact value of venitian ducati and lira at the time. The annual pay of Vivaldi was said to be about 15 o ducati. The ducato was also named zecchino. Goldoni mentioned the value of earrings about 10 zecchini in his play La bottega del caffè.

32 Cesare de Micheli, Letterati e lettori nel Settecento Veneziano, Florence 1979, 153-201.

33 Paola Serra in L. Ricaldone, Le avventure, 5.

34 Lettere di Apostolo Zeno Cittadino Veneziano, Seconda edizione, vol. 3, Venice 1785, 38991: Alla Signora Bergalli a Venezia: "Alla gentile non meno che valorosa Signora Luisa 
to the Conte Collalto as patron for her playwright and gave her detailed instructions on how to write a dedication..$^{35}$ This letter is also very important in order to understand the genesis of the Componimenti Poetici and the edition of the Rime of Gaspara Stampa. In fact, the Conte Collalto was the descendent of the same Conte Collalto who featured as the object of Stampa's love poetry. Zeno advised Bergalli to mention this fact in the dedication. As I will explore later, this connection to Collalto was important for her career as an editor and compiler. As the edition of Agide demonstrates, Bergalli followed the instruction of her mentor precisely. ${ }^{36}$ Zeno also praised Agide to Andrea Cornaro, descendent of an important Venetian family, and emphasised the superiority of Bergalli's writing in comparison with other playwrights of the

Betgalli, Apostolo Zeno felicità e salute. Vienna 9 ottobre 1723: Ho ricevuto e letto con molta soddisfazione il Dramma intitolato Agide, uscito dal Vostro felicissimo ingegno, di cui avete volute farmi parte a titolo di gentilezza; benchè la vostra modestia voglia farmelo credere a fine di correzione. Esso a dirvi sinceramente l'animo mio, mi è piaciuto sovra quanti ne avete per l'addietro composti; e credo, che sarò per dare lo stesso giudicio a favour di quelli che andrete in avvenire scrivendo, mentre con l'esercizio e con lo studio la vostra poesia si va sempre più ripulendo e perfezionando, a somiglianza dei fiumi reali, che più crescono d'acque nel corso, e più acqistano di limpidezza. Lodovi poi sommamente, che lasciati I soggetti favolosi e comuni, vi siate appligliata agli eroici, I quali più degli altri portano la fantasia e dr cose grandi e sublimi, e dove meglio s'intreccia col nobile l'amoroso. Al genio molle del secolo piaciono sulla scena le passion più delicate; ma spesso ancora se nauseano, quando non le trovin meschiate con le più forti. L'une servono all'altre di condimento, come in ben disposto convito alle dolci vivande le aspre e le amare. Il sviluppo del Dramma è facile e natural; ma lo scolgimento è mirabile, non potendo esser meglio pensato e condotto. Al primo Vostro cenno, e alla prima congiuntura ve ne manderò l'esemplare. A riscontro dei versi vi sarà di quando in quando qualche coserella da me notate, più per farvi cosa grata, dacchè me lo richiedete, che perchè ve ne fosse bisogno. Esso poi è dignissimo della protezione del Sig. Conte Barzizi, cui divotamente reverisco, e insieme della pubblica comparsa sopra qualunque teatro: il che un giorno non può mancar di succedere. Le difficoltà che incontrate, non vi sgomentino. I cominciamenti di ogni impresa sono malagevoli e disastrosi: ma finalmente la malignità cede al merito. Nel mio soggiorno di Praga ho parlato a lungo di voi col Sig. Pallavicini, che non si sazia di onorarvi e lodarvi."

35 Lettere di Apostolo Zeno, vol. 3, 454-58: Alla Sig. Luisa Bergalli a Venezia. Vienna 19. Agosto 1724: "Egli è ormai tempo ch'io risponda alla vostra gentil lettera: il che per la mia già superata indisposizione non feci le due settimane passate. Mi son giunti con essa I vostri due Sonetti, I quali mi sono piacuti grandemente, e subito, scritti così di vostra mano, gli ho spediti a S.E. il Sig. Conte Collalto a Pirnitz, luogo di sua giurisdizione nella Moravia, significandogli nello stesso tempo la prontezza e l'piacere, con cui avevate ricevuto l'onore fattovi da lui nell'accettare la dedicazione della vostra Opera. [...]".

36 Agide, re di Sparta. Dramma per musica di Luisa Bergalli da rappresentarsi nel Teatro Giustiniano di san Moise l'anno 1725, consagrado a sua Eccellenza il Signor Antonio Rambaldo, Conte di Collalto, Venice 1725 . 
time. ${ }^{37}$ In another letter of the same year, Zeno encouraged her to continue her new play, ${ }^{38}$ la Placidia, of which no traces remain, ${ }^{39}$ and another one he entitled Arianna, which might have been L'Elenia (as the play contains a character named Ariana). In October 1725, he carefully critiqued Bergalli's play and promised her he would recommend it to the Princess. ${ }^{40}$ The libretto of L'Elenia was published in 1730, set to music by Tommaso Albinoni, and performed at the Sant Angelo theatre. ${ }^{41}$ It is, in fact, dedicated to the Princess of Palestrina, ${ }^{42}$ with whom Bergalli claims female solidarity. Before L'Elenia, in 1728, her

37 Lettere di Apostolo Zeno, vol 4, 17: Al Sig. Andrea Cornaro a Venezia, Vienna 13. Gennajo 1725: "Vi ringrazio delle novità teatrali. Il Seleuco che si ricita in S. Angelo, è l'Antico fatto in S. Cassano già molti anni da me e dal Pariati. Non è cattiva opera, ma non delle mie migliori, e dà troppo nel melancolico; e quanto a me, non avrei dato agli impressarij consiglio di riporla sul teatro. Ho però caro, che non dispiaccia, e che sostenga il credito del teatro. Ho riletto l'Opera della Bergalli, che sempre più mi è piaciuta. Ella è condotta e scritta assai bene, e fa vergogna a tante puerilità e sciocchezze, che escono alla giornata della penna di cotesti poetastri."

38 Lettere di Apostolo Zeno, vol. 4, 40-41: Alla Sig. Luisa Bergalli a Venezia. Medlin, 26. Maggio 1725 .

39 See also Luisa Ricaldone, "La passion per il teatro di Luisa Bergalli", in Luisa Bergalli, poeta, drammaturga, traduttrive, critica letteraria. Atti del convegno ed. Adriana Chemello, Mirano $2008,47-58,56$.

$40 \quad$ Lettere di Apostolo Zeno, vol. 4, 63-64: Alla Sig. Luisa Bergalli a Venezia. Vienna 13. Ottobre 1725: "Ho ricevuto il Vostro Dramma. L'ho letto e riletto con piacere. E scitto assai bene, e assai bene caratterizzato, e condotto. Si sostiene dal principio al fine ugualmente in tutte le sue parti, e me rallegro con voi. Permettetemi solo che con libertà vi dica il mio sentimento. Temo molto, che nel terzo atto la sua rappresentazione riesca troppo asciutta e melancolica, per essere appunto troppo ripiena di passion e di affetti. Lo stesso finimento lascia disgusto nell'animo degli uditori, I quali avrebbono desiderato di veder contenti I due principali personaggi, Placidia e Costanzo, la cui virtù le rende sin da principio sì interessati nella loro felicità. Non può con ragione darsene a voi biasimo di avere fatto in tal guise, avendo seguitato la vera istoria, che obbliga Placidia alle nozze con Ataulfo, costrettavi dalla necessità di salvar così la sua patria. Ciò fu cagione ch'io alter volte avendo posto l'occhio su tal soggetto, nè trovando rimedio al male, non mi sono rischiato nè di alterarlo, nè di esporlo sopra il teatro: ma presone il midollo, lo applicai ai successi di Fl. Anicio Olibrio, che dal Sig. Patriati e da me unitamente fu verseggiato. Vi do col mio sentimento, non con oggetto di farvi opposizione, ma solo a fine di dirvelo sinceramente, poichè così mi comandate. Ciò nonostante farollo trascrivere in buona maniera; e lo stesso faro dell'Arianna, quando mi giunga: ed io stesso allora, di consenso del Sig. Principe Pio, Cavaliere sopra la Musica, presenterò l'uno e l'altro componimento all'Imperatrice Regnante, alla quale il Vostro ingegno e merito è assai palese, e che desidera di vedere qualche altra cosa di Vostro. Il Sig. Antonio Pellegrini, insigne Pittore, e cognate della Sig. Rosalba, il quale ora è qui [...]."

41 Sama, "On canvas and on the page", 128.

42 L'Elenia. Dramma per musica. Da recitarsi al Teatro di S. Angelo l'anno 1730 dedicata a S.E. Donna Teresa Buoncompagni, Barberini, Principessa di Palestrina, Venice 1730, 3-5: "Voi, o Eccelentissima Principessa, [...] Mi giova però di credere, che non vogliate in questa 
tragedy Teba, inspired by the French tragedy of Racine, was published with a dedication to Marco Miani. ${ }^{43}$ Bergalli did not sign the play and no information exists about its performance on the stage.

Unfortunately, Zeno's correspondence does not provide any information about the material details of Bergalli's relationship with the theatres or the publishers. It does, however, demonstrate the ongoing importance of patronage: the central theme of Bergalli's comedy Le avventure del poeta, which she wrote in $1730^{44}$ as demanded by her future father-in-law Iacopo Antonio Gozzi, to whom the play is also dedicated. In the dedication letter, the author emphasises her devotion to the aristocratic family and underlines on the other hand the autobiographical inspiration of the playwright. ${ }^{45}$ Knowing both her future and the playwright, the dedication acquires an ironical character.

The comedy, which is in five acts and in hendecasyllable (endecasillabo) verse, is in contrast to classic comedy in that it has no love plot. Instead, it details the life of a poor poet, Orazio, who tries to earn money through his poetry in order to feed his sister, Camilla, and his father, Ridolfo. Even if he writes poorly, he must come to terms with the fact that he is not able to earn money with his literary activities as patronage no longer functions. So Camilla, his intelligent and pragmatic sister, earns money for the family by doing needlework. Bergalli doubled her own personality in the two main characters, Orazio and Camilla, and perhaps for reasons of bienséance, she avoided making Camilla a female poet. When the patron, Conte Valerio, comes for the first time to the home of Orazio's family, he suggests Camilla also pursue a literary

occasione dar luogo al Vostro discernimento, in modo, che l'innata vostra gentilezza non abbia campo di sosternermi, e di parlarvi a mio vantaggio. Donna come io sono, giovine, ed inespersta, lontanissima dal pensiero di riscuotere applause, merita certamente da voi compatimento e protezione [...]."

43 Teba. Tragedia dedicata a sua eccellenza il Signor Marco Miani, Venice 1728.

44 Luisa Bergalli, Le avventure del poeta, Commedia, Venezia, Cristoforo Zane, 1730.

45 Le avventure del poeta, ed. Ricaldone, 19: "All'illustrissimo Signor Iacopo Antonio Gozzi Sign. Padron mio Colendiss. Ha per lo appunto un anno, che mi faceste commanda, Illustrissimo Signore, di scrivere una qualche commedia; e cioè che non mi lusingava poter ottenere per forza di mio prorio istinto, mi venne fatto per valore di Vostro cenno. Ella è questa intitolata; delle quali guardando in un certo modo a me stessa d'interno, mi pare talento di scrivere. [...] Dall'altra parte so certo, che s'io ne taccio, pregiudicando insieme al vostro merito, e al mio dovere: così per non donar troppo a me, e per non togliere troppo a voi, parmi bene di accenar solamente una qualche cosa, tra le molte, che sotto slilenzio passer io voglio. Permettetemi dunque, ch'io dica, come di antichissime nobiltà potete vantarsi, così che furono I vostri [...] Quel ddi che più mi console à l'aver a vederela vostra famiglia sempre più che mai stabilita nel suo decoro [...]. Umil. Devot. Obblig. Serva Luisa Bergalli." 
career. ${ }^{46}$ But the situation of her brother has already revealed to her that money is difficult to earn by writing. ${ }^{47}$

The Conte is not only cruel, but also uncultured. The only person who is willing to pay Orazio is the merchant Prospero; his generic name stresses the prosperity of the bourgeois class of eighteenth-century Venice. In the end, Orazio rejects his literary aspirations and accepts the position of professional writer at the court of Lorena. There was no satisfactory ending for the poet in the Venetian context. The only positive element is the Conte's eventual realisation about his behaviour. ${ }^{48}$

With her comedy, Bergalli is not only one of the few authors in the eighteenth century who focuses on the situation of the poet, but she preceeds Carlo Goldoni's comedies in more than one respect: firstly, in the realistic social satire of Venetian society of that time and through the characters of Conte Valerio and his wife Bianca, Bergalli describes the decadent society of eighteenth-century Venice. The couple is arrogant, ignorant and cruel, and they have not yet understood how the system of exchange of work and money functions. They try to reward Orazio with symbolic prizes: admission to the Arcadia Academy, a portrait and other kinds of gifts. Perhaps, here lies an ironic perspective of Bergalli's own situation. Camilla, as the rational member of the family, is the one to complain about this misunderstanding. ${ }^{49}$

In opposition to Camilla, who is able to feign interest to create a positive impression on the Count in order to earn money, ${ }^{50}$ Orazio represents intrinsic motivation, sincerity and virtue. ${ }^{51}$

46 Ibid., 23: "Val. Ritornar, che hanno a fare I complimenti/ Presso di un cavalier, che vuol, che siete/Tutti di casa sua? Ditemi, è forse /Poetessa anch'ella? Rid.Illustrissimo, no:/ Na ben vorri, che anch'ella ormai lasciami/Questi vili esercizj, ed attendere/Agli studij: che certo diverebbe/ Una novella ... una novella ... Val.Saffo/."

47 Ibid., 26: "Cal. Che sia pure maledetta quel'arte dei poeti, /Che bevon sempre al fonte di Elicona,/E non mangiano mai. Povero Orazio,/Ha ben ragione quando si lamenta”.

48 Ibid., 8o: "Val. Signor Orazio, veramente veggo/Il nostro torto, e se adesso dovessi/Ricominciar a favorirvi, il altra/Guisa lo vorrei far".

49 Ibid., 28: "Cam. [...] ma perché I ricchi, I nobili/Non sono tenuti a pagarvi? Or. Perchè, / Come dice Diogene, fa senso/ Agli uomini quell uom solo nel vil/stato cader possono anch'essi sentono/Pietade, ver bi grazia per un cieco, Per uno Storpiato, perché ciechi,/E storpiati devenir potrebbero/Ach'essi: ma con un poeta cosa/hanno a che far? Ti par mai, che letterati/O amanti di virtù divenir possano?"

$50 \quad$ See Pamela D. Stuart, "Eroine della dissimulazione. Il teatro di Luisa Bergalli", Quaderni veneti (19 June 1994), 73-92.

51 Paola Serra in Le avventure del poeta, ed. Ricaldone, 11: "Se Camilla, avvalendosi del buon senso pratico di cui è riccamente investita, è la coscienza lucid ache esprime la contradizzione. Orazio rappresenta invece l'uomo di lettere nei suoi aspetti di idealismo, di 
On the other hand, there is the merchant Prospero, the only character willing to pay for Orazio's sonnets. He represents the values of the new middle class, strangers to the traditions and customs of the old aristocratic class. Prospero knows that work merits payment. A crucial moment in the play occurs in Scene 4, Act III, when the Conte and Prospero - the old and the new world confront one another. While the Conte disapproves Prospero's willingness to pay Orazio and worries about the possible reactions of the Academy of Arcadia, ${ }^{52}$ Prospero defends the material value of poetical work. Ridolfo represents the ancient world through his admiration for aristocracy. His desire to be a part of this world may have been inspired by the Bourgeois Gentilhomme of Molière.

It is to Bergalli's merit that she tried to renew the Italian Comedy before Goldoni. The plot is incomparable with the Commedia dell'Arte and, moreover, Bergalli rejects the use of traditional masks. Her comedy is inspired by a sense of reality and social critique, like Goldoni's was later, in the middle of the century. The subject of her critique is Venetian society, in which her portrayal of aristocratic protagonists compares to the aristocrats of Goldoni's Locandiera, such as the Marchese di Forlipopolo. Like Goldoni after her, Bergalli revalues the role of bourgeois working people. Orazio resembles Pandolfo of La bottega del caffè and Camilla resembles Mirandolina, because of her pragmatism and her ability to pretend. The comedy functions as a kind of self-fullfilling prophesy that previews Bergalli's future life with Gasparo Gozzi.

\section{The Publication of the Componimenti Poetici and the Rime of Gaspara Stampa}

The publication of the Componimenti Poetici delle più Illustri Rimatrici d'Ogni Secolo ${ }^{53}$ must also be seen in the context of Bergalli's relationship to Apostolo Zeno, who was the initiator - as friend of Crescimbeni - of the Arcadian dependence of Venice (L'Accademia degli Animosi). ${ }^{54}$ In 169o, Gian Vicenzo

purezza, talora di ingenuità, ma anche di corretezza morale e di professionalità: una figura inno vativa di intellettuale, caratterizzata da un insieme di virtù non ancora apprezzate socialmente, ma che tendon a fare del letterato un individuo sempre più dignitoso e sempre meno disposto a riconoscere come intrattenitore di una certa classe rappresentativa del potere".

Le avventure del poeta, ed. Ricaldone, 55: "Indietro il vostro ducato, uom da bene;/Ed imparate a conoscere cosa/sia trattar co' poeti di tal sorta./El non ci manderebbe altro, che gli Arcadi/ sapesse questa ...". 
Gravina and Giovanni Mario Crescimbeni founded the Accademia dell' Arcadia in Rome, from the Accedemia Reale of Christina from Sweden, in order to fight against the bad taste of baroque poetry and to defend the tradition of petrarchism. In 1726, the Accademia dell' Arcadia already had over 40 colonies all over Italy, including the Colonia degli Animosi in Venice. In contrast to the Renaissance academies, the Arcadia accepted women as members and became an important stronghold for female literary activity. ${ }^{55}$ It was customary to publish anthologies of the members of Arcadia and it is not so astonishing that the project of the Componimenti was also guided by Apostolo Zeno. ${ }^{56}$ The Componimenti of Bergalli, in the tradition of the anthologies of Domenichi ${ }^{57}$ and Recanati (1716), was published in two volumes by Antonio Mora: the first, containing 112 women poets of the past and, the second, containing approximately 136 women poets from 1575 up to those still living. The list of the second volume was completed by Zeno and, in a cited letter, he recommends that she also read Crescembeni's Comments. ${ }^{58}$ Zeno also mentions that she should be patient with the second volume and only publish the first. But Bergalli ignored

55 See Tatiana Crivelli, “L'Arcadia femminile: spazi reali e simbolici di un'interazione culturale", Höfe-Salons-Akademien. Kulturtransfer und Gender im Europa der Frühen Neuzeit, eds Gesa Stedmann, Margarete Zimmermann, Hildesheim/Zürich 2007, 241-54.

56 Lettere di Apostolo Zeno, vol. 4, 123-26: Alla Sig. Luisa Bergalli a Venezia. Vienna 20 Luglio 1726: "Ho ricevuto con la vostra gentil letter ail catalogo delle rimatrici, delle quali porrete I componimenti nella vostra raccolta. Ho osservato che ve ne mancano parecchie, d'alcune delle quali a piè di questa troverete segnato il nome. Presso di me non hoc he pochissimi libri di poesie italiane, avendoli tutti lasciati press oil Sig. Andrea mio fratello. Il P. mio fratello, come più pratico, potrà farveli vedere, acciocchè ne facciate buon uso. Egli è bene, che diate un occhiata all'Istoria, e ai Commentarj del Crescembeni, nei cui volume ne troverete nominate moltissime, che non avete osservate, ed egli vi dirà I libri, ne' quali I componimenti s'incontrano, e s'io gli avrò, avrete modo di ricopiarli. Veggo che avete fretta di dar fuori la vostra raccolta, per non perder l'occasione della dedicatoria al Sig. Cardinale Ottoboni. Ma queste sono cose da potersi fare all'infretta, e su due piedi, come suol dirsi: ma han di bisogno di mature esame, e di lunga diligenza e fatica. Pure se non potete fare altrimenti, date fuori quello che avete raccolto, col titolo di I. Volume, riservandovi a darne la continuazione in altri. Così vi torrete di dosso l'accusa di aver tralasciato, e avrete modo di averne da alter parti. Circa le notizie, poche ne sfuggiranno a voi e al fratello, delle quali io possa servirvi. Lo faro tuttavolta, qualora ne sia da voi dimandato. Saluto tutti di vostra casa, e le Sigg. Carriere; lo stesso fa a voi il Sig. Conte di Collalto che loda molto il Vostro disegno, e vi raccomanda la sua M. Gasparina, della quale è stato fatto tanto onore alla sua casa nella persona del Conte Collaltino da lei amato, [...]."

57 Lodovico Domenichi, Rime diverse d'alcune nobilissime e virtuosissime donne, Lucca 1559; Giovanni Battista Recanati, Poesie italiane di Rimatrici viventi raccolte da Teleste Ciparissiano, Venice 1716 .

$5^{8}$ Giovan Mario Crescimbeni, Commentari intorno alla sua Istoria della volgar poesia (1702). 
the suggestions of her mentor; according to Adriana Chemello, the editor did not accept this solution because they received permission to stamp quickly.59

The anthology was dedicated to Cardinal Pietro Ottoboni, a Venetian protector of the Arts. In her preface to the readers, Bergalli notes two reasons for her work: firstly, she wants to reinstate women's poetry and, secondly, she also expects some honour for her own person. She accompanies the preface with a long citation from Moderata Fontes epic poem Floridoro (1581), in which the Renaissance poet underlines the equality of men and women in the field of literature. Bergalli also refers to the long tradition of women writing of the Serenissima. At the end of her preface, she thanks all those who provided her access to libraries and gave help and advice, such as Giacomo Soranzo, Antonio Sforza, her latin teacher, and Apostolo Zeno. Interestingly, at the end of his letter, Zeno also recommends the second edition of Gaspara Stampa's Rime ${ }^{60}$ published after the death of Stampa - which was published at the request of the Conte Collalto, one of the important patrons of Bergalli. Her act of remembering women's literary productions must be seen within the context of the Arcadian patronage system, which favoured the high consciousness of female authorship by Bergalli. Furthermore, with the publishing of the Almanacco delle donne ${ }^{61}$ (a very popular genre which usually had a great number of readers), the participation of Bergalli cannot be proved by any source other than Tiziana Plebani. The editor of the modern edition of the Almanacco ${ }^{62}$ argued that Bergalli might have contributed to the volume. ${ }^{63}$ In any case, it would have been a nice opportunity for her to earn some money by reusing the Componimenti for a large audience.

\section{The Literary Activity of the Gozzi Couple or How to Earn Money by Writing}

Luisa Bergalli was married to Gasparo Gozzi on 8 July 1738. As mentioned in the introduction, the family's financial situation was poor during this period and Gasparo was not able to resolve the debts of their already large family,

59 Adriana Chemello, "Le ricerche erudite di Luisa Bergalli", in Geografie e genealogie letterari. Erudite, biografe, croniste, narratrici, épistolières, utopiste tra Settecento e Ottocento eds Adriana Chemello, Luisa Ricaldone, Padua 2000, 49-88, 55 .

6o Rime di madonna Gaspara Stampa, con alcune altre di Collaltino, e di Vinciguerra conte di Collalto, e di Baldassare Stampa, Venice 1738.

61 Almanacco sacro e profano per l'anno santo 1750 in difesa delle donne, Venice $175^{\circ}$.

62 Almanacco delle donne, ed. Tiziana Plebani, Venice 1991.

63 Adriana Chemello, Le ricerche, 81 . 
to which the couple added another five members. During the first six years of their marriage, ${ }^{64}$ Bergalli, presumably absorbed by the consecutive birth of her five children, published only one tragedy in $1743 .{ }^{65}$ The first collaborative literary project of the couple, conducted in order to earn money, was the translation of Fleury's monumental Histoire ecclésiastique, mentioned by Gozzi in his correspondence. ${ }^{66}$ The project was assigned to Bergalli, but it was Gozzi who handled transactions with the editor. He was also preoccupied with the progress of this monumental project (27 volumes with over 12,00o pages), which was published in 1766 only under the name of Gasparo Gozzi. Bergalli translated the first volume, due to her consecutive pregnancies Gozzi had to help her with the remaining volumes. In a letter, Gozzi admits that she was the better translator, but that he was pleased to see the work attributed to him. The genesis of this project reveals the real conditions of married women and literary activity in eighteenth-century Venice. Once married, women of the ancien régime often did the work for publications attributed to her husbands. Another example is that of the German translator Luise Adelgunde Gottsched. ${ }^{67}$

The second project the couple started in order to earn money was the direction of the theatre Sant'Angelo in Venice in 1747/48. If the assertions of Carlo Gozzi in his Memories ${ }^{68}$ and fragments of the memoirs of his son Francesco are

64 See also Fabio Soldini, "Luisi Bergalli e I Gozzi", in Luisa Bergalli, poeta, drammaturga, traduttrive, critica letteraria. Atti del convegno ed. Adriana Chemello, Mirano 2008, 33-46.

65 Elettra. Tragedia da rappresentarsi nel teatro Grimani di S. Samuele, Venice 1743.

66 Gasparo Gozzi, Lettere, ed. Fabio Soldini, Parma 1999, Lettera 30 Ad Anton Federigo Seghezzi, Visinale 22 dicembre 1740, 63-64: "Vi ringrazio con tutto l'animo degli avvertimenti intorno alla Traduzione [Storia ecclesiastica del Fleury, RvK]. Certamente la vogliono con tanta velocità, che sarà cagione di qualche scandalo. E quell'Antipater ve ne dia prova, che perdio non può essere per altro, che per troppa furia. Non per iscusar me, ma per dire la verità a voi, dicovi che ho gran maraviglia, che quella traduzione sia creduta mia, perché il Mozzati sa bene d'averla data a mia moglie, non a me; e non so come il Pecori [il stampatore veneziano Carlo Pecora; RvK] creda altrimenti. Anzi avendo io detto, che non mi sentiva da poter prendere quella faccenda sulle spalle, e ch'io lo pregava dar la versione a mia moglie, egli se ne contenta, e il libro lo diede a lei, come a più veloce, e più continua nell'opera; e così ella scrisse il primo tomo. Ma nel secondo vedendo che la si uccideva sotto la fatica, e non poteva [p. 64] nella prestezza continuare la fretta dello stampatore, ho incominciato a soccorrere anch'io qualche ora del dì. Tutte queste cose vi dico sotto il seggello della fede; [...]"

67 Rotraud von Kulessa, "La traduction allemande de Cénie de Françoise de Grafigny", in $L a$ traduction des genres non romanesques au XVIIIe siècle, eds Annie Cointre/Annie Rivara, Metz 2003, 315-28.

68 Carlo Gozzi, Memorie inutili, 148: "[...] fui avvertito che la moglie di mio fratelleo, sempre progettante poetica e sempre vaga di maneggi e d'amministrare, aveva sedotto il povero mio fratello, facendogli credere e vedere mentalmente delle montagne d'utilità a firmare la scrittura della condotta del teatro di Sant' Angelo in Venezia, e non so quante scritture di 
to be trusted, ${ }^{69}$ Bergalli initiated the project. Francesco described the situation of the family in these years in the following words: "There were ensuing divisions in our family. But before they could be arbitrated, my father had to think about his literary studies and my mother translated from Latin and French in order to maintain fourteen persons". ${ }^{70}$ The family was so much in debt that they had to to leave the Palace of San Cassiano to the merchant Francesco Zini, and move to a modest apartment in San Giacopo dell'Orio. With these conditions, it is unsurprising that Bergalli's project did not succeed. She tried to save money by casting cheap actors, which partly contributed to the failure of the project. Two of the first actresses were unable to satisfy the public at the first performance, and Francesco noted a riot amongst the spectators. The company also tried its chance on the Terreaferma and turned back to Venice where the performance of Gasparo Gozzi's Esope was a modest success. The plays performed were translations from French of Boursault and Destouches, and another, $\mathrm{La}$ Bradamante, with an uncertain attribution to Bergalli. ${ }^{71}$ The Gozzi couple attempted to reform Italian theatre as Elisabetta Caminer Turra did later with her translations from French drame bourgeois. ${ }^{72}$ Nevertheless, the theatre project could not be saved. Bergalli was even forced to reduce expenses for the orchestra lighting and, according to Francesco, replaced oil with fat-burning lamps, to the protests of the audience. In the end, Gozzi had to pay the actors, along with the two first actresses, by ensuring their house as a life annuity.

After this disastrous experience, Francesco described a calmer period in which the couple tried again to earn through translations. ${ }^{73}$ One of their last

stipendio ad una truppa di comici, che dovevano agire ad una rovina, ma ch'ella conteggiava per un opulente vantaggio, facendosi impresario, direttrice e sovrastante e seguace alla truppa ne' teatri dei Venezia e di terraferma. Avrei voluto non avere questa notizia. Benché ella desse un'idea delle anteriori direzioni tenute e mi servisse di giustificazione, non ebbi alcun sentiment allegro, e compiansi il fratello e gl'innocenti suoi figli. Tentai, senz'essere nominato di far dissuadere quella femmina rovente sopra una tale impresa. Ributtò ogni persuasion tentata, certissima d guadagnar de' tesori da far mordere le dita d'invidia a' di lei cognati ..."

69 Soldini, "Contributo".

70 Soldini, "Contributo", 374, note 1. "Ne sguirono le divisioni in famiglia. Ma prima che queste si concludessero, toccò a mio padre di dover pensare col suo letterario studio, e a mia madre che traduceva dal francese e latino, a dare mantenimento a quatordici persone [...]"

71 See Soldini, “Contributo", 376, note.

72 Rotraud von Kulessa, "Elisabetta Caminer Turra. Traductrice, médiatrice et 'organisatrice culturelle', in Femmes écrivains à la croisée des langues 1700-2000, eds Agnese Fidecaro, Henriette Partzsch and Suzan van Dijk, Genève 2009, 55-66.

73 Soldini, "Contributo", 384 : "Raccolta in questa casa la dispersa famiglia, pareva che le cose avessero preso una qualche piega di buon Sistema e che tutti stesero al sordo. Traduceava per vadagno mia madre dal francese, così faceva mio padre." 
chances to profit from translation was on the occasion of the visit of French poet Anne-Marie du Boccage to Venice in 1757. Bergalli translated her tragedy Les Amazones, which was published with portraits of the two authors in a prestigious bilingual edition in $1756 .{ }^{74} \mathrm{Up}$ until $176 \mathrm{o}$, she published only occasional poetry and an anthology of female poets dedicated to Caterina Dolfina Tron, ${ }^{75}$ who was a protector of the Gozzi's. ${ }^{76}$ After her death in 1779, her son Francesco complained that all the rights of the literary productions of his mother were in the hands of an editor, which left him without his inheritance. ${ }^{77}$

\section{Conclusion}

Eighteenth-century Venice is often considered the birthplace of professional writing due to its flourishing publishing industry, numerous theatres and the work of Carlo Goldoni. However, according to Mario Infelise, Goldoni was an exceptional new type of intellectual who was able to work more or less independently from patronage. ${ }^{78}$ The case of Luisa Bergalli Gozzi is revealing: it shows, in an emblematic way, the difficulties of the shift from patronage - as a system that no longer functioned in a rising bourgeois society - to professional writing in the middle of the century, as demonstrated in Bergalli's play $L e$ Avventure del Poeta. The Gozzi couple belongs to a group of authors who attempted to live from their writing, but never really succeeded. ${ }^{79}$ Furthermore, Bergalli is a striking example of a woman still active in the literary field, and privy to its difficulties, once married.

74 Le Ammazoni.

75 Rime di donne illustri a su aeccelenza Caterina Dolfina cavaliera e procuratessa Tron nel gloriosissimo ingresso alla dignità di procuratore per merito di San Marco di sua eccelenza cavaliere Andrea Tron, Venice 1773.

76 Soldini, "Contributo", 395.

77 Soldini, "Contributo", 397: "Prima di morire e della sua agonia, alla presenza di due testimony, con una carta da lei sottoscritta mi lasciò erede tutte le sue azioni e ragioni. Non parlo della sua eredità, degli effetti mobile di sua ragione a me rimasti, perché un zero formerebbe il valore di quelli. Mi ha spiaciuto moltissimo l'aver ella in vita passate le sue opera letterarie a certo stampotore che non potei mai rinvenire, e così non ho ne pur pottuto essere erede delle sue composizioni: questo é per lo più il fine degli uomini letterati e delle persone di merito."

78 Mario Infelise, L'editoria, 198.

79 Mario Infelise, L'editoria, 194: “[...] ma sempre di più nella seconda metà del Settecento furono coloro che cercarono di trasformare l'attività intellettuale in un mestiere come tutti gli altri. Erano spesso laici, [...] ed arano borghesi o esponenti della piccolo nobiltà, privy di rendite cospicue. In tal senso Gasparo Gozzi è una figuara emblematica. Anch'egli tra 
The patronage system is still relevant for the most prolific period of Bergalli's literary career, the time in which she had a well-known male mentor, Apostolo Zeno, who recommended her to some influential patrons and theatres. Once married, she worked less as an autonomous writer and financial negotiations seem to have been carried out by her husband. Gradually, Bergalli lived in the shadow of her husband and material sorrows about the debts of their large family became more significant than the pursuit of literary fame. The case of Bergalli is a tragic one; she was excluded from literary history and the history of translation, while her husband received relative literary fame. Her life may disappoint the modern reader, but it likely reflects the real condition of women's writing in the first part of the eighteenth century. She was certainly not alone; similar cases include Elisabetta Caminer Turra, who was also witness to the trials and tribulations of Venetian women attempting to succeed in this field, ${ }^{80}$ and avoid an ambiguous position so as to receive symbolic or economic capital. ${ }^{81}$ As the example of Luisa Bergalli Gozzi shows, it was more difficult for a woman to be accepted as a writer and to earn money from literary activities. Exposed to the unfounded accusations of her brother-in-law, Carlo Gozzi (known for his misogynistic attitude), she refused recognition and limited her literary activities to anonymous translations.

\section{Bibliography}

\section{Primary References}

Bergalli, Luisa. 1750. Almanacco sacro e profano per l'anno santo 1750 in difesa delle don$n e$, Venice: Modesta Fenzo.

Bergalli, Luisa. 1991. Almanacco sacro e profano per l'anno santo 1750 in difesa delle don$n e$ (ed. Tiziana Plebani). Venice: Ippocampo Editrice.

Bergalli Gozzi, Luisa. 1725. Agide, re di Sparta. Dramma per musica di Luisa Bergalli da rappresentarsi nel Teatro Giustiniano di san Moise l'anno 1725, consagrado a sua Eccellenza il Signor Antonio Rambaldo, Conte di Collalto. Venice: Marino Rosselli.

gli anni Quaranta e Cinquanta tentò di mantenersi soprattutto scivendo. [...] ma gli non ebbe fortuna. Le retribuzioni dei librai non gli consentirono di eviatre molti umiliazioni e le inizitive di vario genere che intraprese non sempre andarono a buon fine."

80 Rotraud von Kulessa, "Elisabettea Caminer Turra".

81 Rotraud von Kulessa, Entre la reconnaissance et l'exclusion. La position de l'autrice dans le champ littéraire en France et en Italie à l'Epoque 19oo, Paris 2011. 
Bergalli Gozzi, Luisa. 1728. Tragedia dedicata a sua eccellenza il Signor Marco Miani. Venice: Cristoforo Zano.

Bergalli Gozzi, Luisa. 1726. Componimenti poetici delle più illustri Rimatrici d'ogni secolo. Venice: Antonio Mora. Available on http://artflx.uchicago.edu/cgi-bin/philologic/ navigate.pl?iww.7 (consulted 26.o3.2014).

Bergalli Gozzi, Luisa.173oa. Le avventure del poeta, Commedia. Venice: Cristoforo Zane. Bergalli Gozzi, Luisa. 173ob. L'Elenia. Dramma per musica. Da recitarsi al Teatro di S. Angelo l'anno 173odedicata a S.E. Donna Teresa Buoncompagni, Barberini, Principessa di Palestrina. Venice: AlviseValvasense.

Bergalli Gozzi, Luisa. 1733. Le commedie di Terenzio tradotte in verso sciolto (col testo latino al fianco). Venice: Cristoforo Zane.

Bergalli Gozzi, Luisa. 1736/37. Opere di M. Racine, 2 vols. Venice: Domenico Lovisa.

Bergalli Gozzi, Luisa. 1738. Rime di madonna Gaspara Stampa, con alcune altre di Collaltino, e di Vinciguerra contoi do Collalto, e di Baldassare Stampa. Venice Francesco Piacentini.

Bergalli Gozzi, Luisa. 1743. Elettra. Tragedia da rappresentarsi nel teatro Grimani di S. Samuele. Venice: Simone Occhi.

Bergalli Gozzi, Luisa. 1745. Il Misantropo. Commedia tratta da Molière, emessa in versi italiani da IrmindaPartenide. Venice: Giambattista Pasquali.

Bergalli Gozzi, Luisa. 1756. Le Ammazoni. Tragedia della Signora Du Boccage. Tradotta nell'Italiana favella da Luisa Bergalli Gozzi, Veneziana. E stampato col testo francese. Venice: Pietro Bassaglia.

Bergalli Gozzi, Luisa. 1997. Le avventure del poeta (ed. Luisa Ricaldone). Manziana:Vecchiarelli.

Bergalli Gozzi, Luisa. 1773. Rime di donne illustri a su aeccelenza Caterina Dolfina cavaliera e procuratessa Tron nel gloriosissimo ingresso alla dignità di procuratore per merito di San Marco di sua eccelenzacavaliere Andrea Tron. Venice: Valvasense.

Chiari, Pietro. 1806. La Francese in Italia o sia Memorie critiche di Madama N.N. scritte da lei medesima. Venice: Antonio Rosa.

Crescimbeni, Giovan Mario. 1702. Commentari intorno alla sua Istoria della volgar poesia. s.l. s.n.

Domenichi, Lodovici. 1559. Rime diverse d'alcune nobilissime e virtuosissime donne. Lucca: Busdraghi.

Gozzi, Carlo. 1910. Memorie inutili. Bari: Laterza.

Gozzi, Gasparo. 1999. Lettere (ed. Fabio Soldini). Parma: Ugo Guanda Editore.

Recanati, Giovanni Battista. 1716. Poesie italiane di Rimatrici viventi raccolte da Teleste Ciparissiano. Venice: Sebastiani Coleti.

Zeno, Apostolo. 1785. Lettere di Apostolo Zeno Cittadino Veneziano, Seconda edizione. Venice: Franco Sansoni. 


\section{Secondary References}

Chemello, Adriana. 200o. 'Le ricerche erudite di Luisa Bergalli' in Chemello, Adriana and Luisa Ricaldone, (eds) Geografie e genealogie letterari. Erudite, biografe, croniste, narratrici, épistolières, utopiste tra Settecento e Ottocento. Padua: Il Poligrafo: $49-88$.

Chemello, Adriana. 2007. 'Luisa Bergalli letterata di chiara fama' in Chemello, Adriana (ed.) Luisa Bergalli. Poetessa drammaturga traddutrice critica letteraria. Atti del convegn. Mirano/Venice: Eidos: 20-22.

Clerici, Luca. 1997. Il romanzo italiano del Settecento. Venice: Marsilio.

Crivelli, Tatiana. 2007. 'L'Arcadia femminile: spazi reali e simbolici di un'interazione culturale' in Stedmann, Gesa, and Margarete Zimmermann (eds) Höfe-SalonsAkademien. Kulturtransfer und Gender im Europa der Frühen Neuzeit. Hildesheim/ Zürich: Olms: 241-54.

Egle Tassistro, Carlotta. [s.d.] Luisa Bergalli Gozzi. La vita e l'opera sua nel suo rempo. Rome: Tipografia Nazionale.

Fajen, Robert. 2013. Die Verwandlung der Stadt. Venedig ind die Literatur im 18. Jahrhundert. München: Wilhelm Fink.

Ferrari, Luigi. 1925. Le traduzioni italiane del teatro tragico francese nei secoli XVII e XVIII. Paris: Champion.

Infelise, Mario. 1989. L'editoria veneziana nel '7oo. Milan: Franco Andeli.

Kulessa, Rotraud von. 20og. 'Elisabetta Caminer Turra. Traductrice, médiatrice et 'organisatrice culturelle" in Fidecaro, Agnese et. al. (eds) Femmes écrivains à la croisée des langues 1700-2000. Genève: MétisPresses: 55-66.

Kulessa, Rotraud von. 2013. 'L'autrice dans l'historiographie littéraire italienne (du 18e siècle jusqu'à l'époque 19oo) et l'identité culturelle' in Keilhauer, Annette and Lieselotte Steinbrügge (eds) Pour une histoire genrée des littératures romanes. Tübingen: Narr (Editions Lendemains 32): 25-36.

Kulessa, Rotraud von. 2014. 'Il gioco con l'illuminismo nel contesto veneziano: I romanzi di Pietro Chiari come esempio di polemica e gioco in letteratura' in Kulessa, Rotraud von et. al. (eds) Conflitti culturali a Venezi dalla prima età moderna ad ogg. Florence: Franco Cesati: $59-74$.

Kulessa, Rotraud von. 2015. 'Elisabetta Caminer Turra (1751-1796) e L'Europa letteraria: alcune riflessioni sulla traduzione' in Circula: revue d'idéologies linguistiques $1-2$.

Mangini, Nicola. 1974. I teatri di Venezia. Milan: Mursia.

Micheli, Cesare de. 1979. Letterati e lettori nel Settecento Veneziano. Florence: Olschki.

Sama, Catherine M. 20o9. 'On canvas and on the page. Women shaping Eighteenth Century Italy' in Paula Findlen, Paula, Wendy Wassyung Roworth and Catherine M. Sama (eds) Italy's Eighteenth Century. Gender and Culture in the Age of the Grand Tour. Stanford: University Press: $125^{-5}$. 
Soldini, Fabio. 1968. 'Contributo agli studi su Gasparo Gozzi. Gli inediti 'Frammenti di Memorie' di Francesco Gozzi' in Giornale storico della letteratura italiana $\operatorname{CXLV}\left(45^{\circ}-451\right): 369-402$.

Soldini, Fabio. 2007. 'Luisa Bergalli e i Gozzi' in Chemello (2007): 33-46.

Stuart, Pamela D. 1994. 'Eroine della dissimulazione. Il teatro di Luisa Bergalli' in Quaderni veneti 19 June: $73-92$.

Zambon, Maria Rosa. 1962. Bibliographie du roman français en Italie au XVIIIe siècle. Traductions. Paris: Sansoni.

Zorzi, Alvise. 200o. Histoire de Venise. Paris: Payot. 